\title{
Howland Award Presentation to Joseph Dancis
}

\author{
SAUL KRUGMAN
}

Department of Pediatrics, New York University Medical Center, New York, NY 10016

It was 7 years ago that I sat in the chair now occupied by Joe Dancis when he presented the Howland Award to me. I did not realize at that time how exciting and thrilling it would be to "play musical chairs."

The first Professor of the Diseases of Children at the Bellevue Medical College, appointed in 1861 and the first Director of the Children's Medical Service of Betlevue Hospital, appointed in 1908 , could not have predicted that three of their successors would be recipients of the prestigious Howland Award-L. Emmett Holt, Jr. in 1966, Saul Krugman in 1981, and today Joseph Dancis in 1988 (Fig. 1). By the way, the first Professor was Job Lewis Smith, Father of the American Pediatric Society and the first Director was Dr. John Howland.

In my acceptance of the award I expressed my gratitude "to Joe Dancis for 35 years of continuous friendship and support, beginning with our arrival on the Bellevue Pediatric House Staff in 1946 after our return from the Second World War, through my tenure as chairman from 1960 to 1974, and followed by his chairmanship during the past 7 years." This statement should be revised to indicate that it is now 42 years since our arrival at NYU and 14 years of chairmanship for Joe.

When I began to prepare this presentation, it soon became apparent that despite my close association with Joe Dancis during the past 42 years, I had limited knowledge of his early childhood. The few references in his curriculum vitae were too limited. How was I to solve this problem? Inasmuch as a straight line is the shortest distance between two points, I discussed my dilemma with Joe when he joined me for lunch in my lab. Several days later he delivered the following handwritten report to me.

Born 3/19/16. no. four of five-all with biblical names: Natalie, Ruth, Mordecai, Joseph, and one with a Hebraic name, Ranana.

Born in Brooklyn, grew up in the Bronx, lived in Manhattan for college years (Columbia College 1931-34), started practice in Queens, moved to Long Island just over the border-the wide-ranging migratory habits of a New Yorker, meaning a New York Cityer.

Growing up experiences were also characteristic of the citybred with little money for the frivolous and the city streets for a playground.

On our street the kids tended to group into two-those who liked ball-playing city-style: punchball, stick ball, handballand those that chose other outlets. We knew each other's world but there was surprisingly little cross-contact, given the limited arena.

School performance was taken seriously in our family -all five children were good students. But school was considered a hurdle as much as a handle to the future; something to pass through as quickly as possible on the way to the serious business of living. Every opportunity to "skip" or jump a class, or enter an accelerated program was grasped. There was no concern, at that time, of social disadvantage of being much younger. That's how I entered Columbia while still in my 15 th year (birthday in March, entered in September). Maybe that's how I was scarred psychiatrically!

I left, after $3 \mathrm{yr}$, for St. Louis University School of Medicine-my first major venture away from home. At that time

Reprint requests Dr. Saul Krugman, Department of Pediatrics, New York University Medical Center, 550 First Avenue, New York, NY 10016. it was a small school living in the shadow of the giant across town-Washington University. After my M.D. degree in 1938, I returned to New York for internship.

Like many of us at that time Joe had a 2-yr rotating internship. During the 1930 s city hospital internships were in great demand. During the first Grand Rounds session of the 1980-1981 academic year at New York University Joe described his experience.

"In general, city hospitals were rated very high. There were evidently lots of patients, and there was very little interference from attendings. It was obvious that if you did a lot, you learned a lot. Somehow the question that whether you did it right or not was not seriously considered.

Let's take a look at these coveted positions. I was so fortunate as to get a job at Queens General Hospital, a municipal hospital and considered a very good catch at the time. The salary was $\$ 12$ per month. Even at that time the city paid better than most other hospitals. I lived on that income for $2 \mathrm{yr}$ as a rotating intern. Some might ask was that living? I thought so.

After all, I got my uniforms free, five of them. In addition, I salvaged some extra uniforms from graduating house staff who to a man never wanted to wear one again. If the graduate was about the right size, judicious use of a surgical scissors to trim the frayed ends made it fairly presentable. The laundry was also free. Each Monday the uniforms were returned starched to an inflexible rigidity. You did not put a uniform on, you broke your way into it. I ate regularly, on the housefour meals a day. The last one at 11:30 PM with the on-coming night staff, a full course dinner. I don't remember the quality of the food particularly but there was a lot of it.

Twelve dollars a month goes a long way when you are on every other night and need the night in between for recovery. You lived at the hospital. Marriage was still considered slightly unwholesome for an intern, and most had not become involved. Most nights off were spent around the hospital. Reading, playing a little pool, dropping in on the emergency room to participate in whatever was going on there.

Were we sorry for ourselves? Not at all and there is no need to feel sorry for us. We didn't know any better and thought we were having a marvelous time-if we thought at all about it. Everyone put in long hours. The nurses had only recently had their regular shift reduced from 12 to $8 \mathrm{~h}$. Life certainly seemed much simpler then. There was work and there was more work, and little time left over for problems."

Joe Dancis and I first met in 1946 during my first visit to Bellevue Hospital when I was fortunate enough to obtain an externship there. By coincidence, I guess that I was wait-listed because 3 months later a residency slot became available. In retrospect our paths to Bellevue Hospital were remarkably similar. Each of us was qualified to begin private practice in July 1941. However, we decided that it would be wise to volunteer for 2 yr of military service before opening an office. On December 7, 1941, Joe who was stationed in Hawaii and I who was stationed in Craig Field, Selma, AL realized that our 2-yr tour of duty would be extended. Our service in the U.S. Army lasted from 1941 to 1946.

When Joe Dancis completed his residency training in 1947 he decided to combine private practice with his interest in pediatric research and teaching. Joe and I had an intensive exposure to 


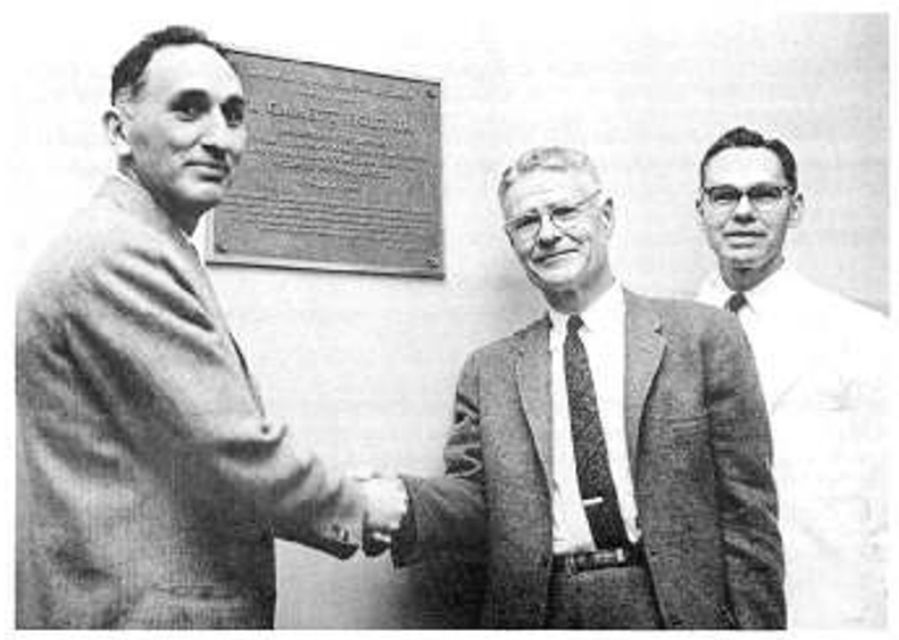

Fig. 1. Howland awardees L. Emmett Holt, Jr., 1966; Saul Krugman, 1981; and Joseph Dancis, 1988.

the atmosphere created by Emmett Holt, thereby causing an infection that was characterized by a desire to pursue an academic career.

Shortly after his arrival at Bellevue Hospital Joe observed that no one on the staff was interested in the problems of the newborn infant (during the 1940s the title of "neonatologist" had not been conceived). He asked Dr. Holt if he might try to fill the vacuum. Emmett Holt's response was a shock for Joe. He asked him to write the chapter on the subject for the 12th edition of his text on Diseases of Infancy and Childhood. He assured Joe that he would become an expert in the process. History has proved that Emmett Holt's prediction was accurate. Oh, for the good old days when one could become a neonatologist without all those Board requirements and exams!

When a seed is planted in fertile soil it will eventually grow and flower after exposure to sunshine, water, and the appropriate climate. I believe that a seed was planted in Joe Dancis shortly after his arrival at Bellevue when he was assigned to the infants' ward. He described his experience during his 1980 Grand Rounds presentation.

Our infants ward, G-8, housed some fascinating diagnostic problems. I am going to tell you about one of them, because this is what is now called a human interest story. Also it makes me look pretty good, so if you listen carefully you will find that all I did was to pay attention to what the nurse was telling me.

Soon after I arrived at Bellevue, I was assigned to G-8. As was customary in those days, and probably still is, the new intern was often given the bulkiest chart and so I was handed the chart of little Linda, a 3-month-old charming child with a fever of undetermined origin. As I waded through her chart there was little question that she was running a low grade fever, and it did not seem to have any particular rhyme or reason. Bacteria wandered in and out of her urine, also without any particular rhyme or reason. There was a bizarre $x$-ray that had been initially diagnosed as hydronephrosis at Mt. Sinai before the child was shipped to Bellevue, but this had later been shown to be the consequence of over distension with dye. The child was small and there were innumerable blood counts, blood cultures, urine cultures, $x$-rays which had not cured the fever.

At that time the chief nurse in the infant ward was an intelligent, energetic woman who also happened to be the wife of the chief resident. I thought I had already quizzed her thoroughly about Linda. This time she joined me at the crib side as I was going over the baby again, and this time she commented that when the bottles of water were distributed around the ward, Linda would seize hers eagerly and drink avidly. This piece of information was something like a bomb bursting, or angels singing, or whatever. But it was easy sailing from thereon. I asked the nurse to offer water to Linda as often as she would take it and she took it very often and the low grade fever abruptly disappeared. The chief resident (John Birmingham) and I then proceeded to study the child with great care. It took a long time because as I have already indicated, the house staff did not have much extra time. Before we finished we had documented that Linda had pituitrinresistant diabetes insipidus. Linda was almost $1 \mathrm{yr}$ old, she had grown increasingly attractive and charming, and had become the favorite of the entire housestaff.

But that does not finish the story. John Birmingham and I had become close friends during the year. One evening we were having a swim at the Madison Square Boys Club, which still exists right near Bellevue. He picked that occasion to announce that he and his wife had decided to adopt Linda. Just a jump ahead to finish the story. Linda is now in her thirties, and has children of her own. She returned to visit her first home in Bellevue about 5 yr ago. A most attractive young woman, who gave me great pride as I ushered her about.

This experience was published in the first article listed in Joe's bibliography. The paper by Dancis, Birmingham, and Leslie entitled "Congenital diabetes insipidus resistant to treatment with pitressin" appeared in the American Journal of Diseases of Children, vol 75, p 316, 1948.

I know that Joe's outstanding contributions are well know to the officers, council, and members of the American Pediatric Society. His productivity is well documented in his curriculum vitae. Although his bibliography indicates that he is the author or coauthor of 258 publications, it should be noted that he has published 89 papers (170-258) since his appointment as chairman of our department in 1974. Thus, despite the trials and tribulations of elepartmental chairmen during the past decade, Joe has had an extraordinarily productive career in research.

Joe Dancis has been a pioneer in research involving the placenta as an organ of synthesis as well as transport. In addition, he has made major contributions to our knowledge of such genetic diseases as maple syrup urine disease, Lesch-Nyhan disease, dysautonomia and Sellweger's syndrome, with particular emphasis on biochemical elucidation and antenatal diagnosis. During the course of his perfusion studies in the term human placenta his achievements included. 1) Significant advances in the technique of perfusing both sides of a placental lobule. 2) Demonstration of active transport of amino acids in this system, showing considerable variation in different amino acids. 3) Elucidation of the mechanism of lipid transport, demonstrating close correlation between transfer rate and albumin binding for fatty acids and steroids. 4) Studies of vitamin D and riboflavin showing that the binding of 25-hydroxy vitamin D3 to vitamin D binding protein affected its transport rate. He also demonstrated active transport of riboflavin from the maternal to the fetal circulation. In the reverse direction transport is passive.

Joe Dancis' contributions as a member and officer of the American Pediatric Society, as Editor of Pediatric Research and as a consultant to the National Institute of Child Health and Human Development are well known to the officers and members of the council of APS. He has been a loyal, devoted, dedicated member of the Society and a pediatric statesman of national and international renown.

Joe Dancis has been recognized by many awards and honors, such as Markle Scholar in Medical Sciences, Borden Award of the American Academy of Pediatrics, and of course, President of the American Pediatric Society. He was elected an Honorary Member of the Society for Gynecologic Investigation for his contributions to the fundamental physiologic, biochemical, and immunologic problems of reproduction.

I should like to conclude this presentation with a tribute to Bernice Dancis. She supported Joe's crucial decision to leave practice for fellowship training to prepare him for a career in academic medicine. Without her loyalty, love, devotion, and wise counsel it would have been difficult for him to pursue an exciting and highly productive career that culminated in his designation as the 1988 Howland Awardee. 